\title{
Shipscape Influence on the Leisure Cruise Experience
}

\author{
Robert J. Kwortnik, Jr., \\ School of Hotel Administration \\ Cornell University
}

International Journal of Culture, Tourism, and Hospitality Research

2 (4), pp. 289-311

The author thanks Zoe Cohen, a Cornell University undergraduate scholar, for patient assistance collecting data for this manuscript. Send correspondence to Robert J. Kwortnik, Jr., (email: rjk34@cornell.edu; phone: 607-254-6543; FAX: (607) 255-4179), School of Hotel Administration, Cornell University, Ithaca, NY 14853-6902. 


\section{Abstract}

\section{Purpose}

To examine the leisure cruise service environment — the shipscape-and its effects on cruisers' emotions, meaning-making, and onboard behavior.

\section{Design/methodology/approach}

This paper uses qualitative data from 260 cruise customers that was mined from archived online discussion boards. Data were analyzed based on grounded theory and interpretive methods to derive an understanding of shipscape meanings and influences from the cruiser's perspective.

\section{Research limitations/implications}

Given the exploratory research objective and interpretive methodology, generalizability beyond the cruise context is limited. However, research findings suggest not only that ambient shipscape conditions influence cruisers' pleasure, but also that ship layout, décor, size, facilities, and social factors influence the meanings cruisers attach to cruise brands and to the overall cruise experience.

\section{Originality/value}

This paper explores atmospheric effects on consumer behavior in a context as yet examined by tourism and hospitality scholars. The findings extend Bitner's (1992) servicescape framework and reveal novel atmospheric and social effects that influence cruise travelers' experience.

\section{Keywords}

Servicescape, Atmospheric Effects, Cruise Industry, Experiential Product

\section{Paper type}

Research paper 


\title{
Shipscape Influence on the Leisure Cruise Experience
}

\author{
"An RCI ship—or at least, a VOYAGER-class one-feels like a cross between a ship, a \\ resort, an amusement park, and a shopping mall...”” (Host Doug, June 10, 2006, \\ CruiseCritic.com, 2,546 posts)
}

When Royal Caribbean International (RCI) launched Voyager of the Seas in 1999, the cruise line charted a different course for the industry as it sailed into the new millennium. Not only was Voyager a massive vessel at more than 1,000 feet long and 137,000 tons-nearly 30,000 tons larger than recently built “megaships," and capable of carrying more than 3,800 passengers, but the ship featured new design elements never before seen (let alone imagined) on a cruise ship. These innovations included an ice-skating rink, a 9-hole miniature golf course, an in-line skating track, a full-size basketball court, a shopping promenade, and a rock-climbing wall that scaled the back of the ship's huge funnel. These amenities were in addition to the numerous bars and restaurants, spa, fitness center, pools, theater, disco, casino, video arcade, children's play zone, and balconied cabins also found on many new cruise ships.

In 2006, RCI trumped its own Voyager ships by-again-launching the world's largest cruise ship, the 158,000-ton Freedom of the Seas, which featured the industry's first "aqua environment" on the top deck of the ship-including a wave pool for surfing and cantilevered hot tubs suspended 100 feet above the sea, as well as wi-fi capability, cellular phone connectivity, flat-screen TVs in every cabin, and even a boxing ring. Lest one forgets, these ships also sail the oceans, visiting vacation destinations, and providing travelers with an experience that is more traditionally thought of as a "leisure cruise."

Due in part to design innovations that made the cruise product more attractive and accessible to the mass market, the cruise industry is one of the fastest-growing sectors of leisure travel. Nearly 12 million people cruised in 2006, and cruise lines ordered 76 new ships since 2000 to keep up with demand (CLIA 2006a). Industry research indicates that interest in cruise vacations continues to grow and that cruisers rate the experience as highly satisfying and a good value (CLIA 2006b). However, critics of today's cruise industry, from post-modern scholars to the passengers themselves, question what the cruise experience has become or what it should be. Some observers lament the trend of supersized ships and their hedonistic focus (Klein 2002), "McDonaldized" tourist production (Weaver 2005a), and "spaces of containment" intended to maximize revenue capture from passengers (Weaver 2005b). Indeed, Douglas Ward (2005, p. 20), long-time author of the Berlitz cruise guides, argues:

The large floating resorts that travel by night and are in port during the day provide little connection to nature and the sea, the ship being the destination (small town takes to water). Almost everything is designed to keep you inside the ship-to spend money, thus increasing onboard revenue and shareholder dividends.

The cruise industry is in a period of transformation reminiscent of the 1970s when the core product shifted from passenger shipping to cruise vacationing (Masek 2005). More recently, the focus of this transformation is the actual cruise experience, and the medium for change is the servicescape (Bitner 1992), or what is labeled here, the shipscape-the ship itself. Surprisingly, despite the considerable investment required for a new cruise ship (Freedom of the Seas, was estimated to cost a record-breaking \$870 million; Sloan 2006), research on cruise ships as vacation spaces is scant (Conlon, Van Dyne, Milner, and Ng 2004; Yarnal and Kerstetter 2005). 
This study explores the role of shipscapes in the leisure cruise experience. Specifically, this paper examines how cruise passengers interact with shipscapes to shape their cruise experience. Using data culled from an online discussion board dedicated to cruising, this study reveals findings about atmospheric effects and more general themes related to ship design that highlight the importance of shipscapes to cruise passengers. The main contribution of this research is a deeper understanding of the influence of the shipscape on the meanings cruisers create and attach to cruise experiences. The article next provides a brief review of servicescape research along with a glance at the history of the cruise industry to establish a frame of reference for the study. This is followed by a description of the data and analytic method used to derive insights about cruise passengers and their relationship with shipscapes. Findings from this analysis are then reported, followed by a discussion of conclusions and directions for future research.

\section{SERVICESCAPES: A CONCEPTUAL REVIEW}

\section{Servicescapes}

Bitner's (1992) conceptual work on the effects of the service environment on employees' and customers' physiological, psychological, and behavioral responses provides the basis for research on servicescapes (Sherry 1998; Zeithaml, Bitner, and Gremler 2006). The servicescape and its many dimensions, such as ambient conditions, layout, facilities, furnishings, and décor, can influence people in powerful ways. Baker (1986) also proposed that social factors involving employees and customers are aspects of the service environment that can affect the customer experience. Servicescape elements can influence moods and emotions (Pullman and Gross 2004), perceptions of time spent waiting for service (Thomke 2003), and evaluations of service quality (Brady and Cronin 2001). Consumers may draw inferences about employees based on evidence in the servicescape (Bitner 1990). In addition, consumer evaluations of employee cues (e.g., the number and appearance of employees in the servicescape) can affect perceptions of interpersonal service quality and patronage intentions (Baker, Parasuraman, Grewal, and Voss 2002). Servicescapes also can be designed to foster response behaviors such as stay/leave or browse/purchase, as well as social interaction (Sherry 1998; Underhill 1999).

The influence of the servicescape on consumer behavior, decision making, and service evaluations has been studied primarily in retail environments (Sherry 1998; Turley and Milliman 2000; Zeithaml et al. 2006). Borrowing the stimulus-organism-response (SOR) theory of environmental psychology (Mehrabian and Russell 1974), research shows the potential to alter consumer perception in intended-and unintended - ways by controlling myriad design, social, and ambient cues in the environment (Baker et al. 2002). The effects of ambient factors such as music, smell, and lighting have been of particular interest to consumer researchers, as these characteristics can be experimentally manipulated to test for cause-and-effect relationships (for reviews see Ezeh and Harris 2007; Turley and Milliman 2000). This research reveals the inherent complexity of servicescape strategy due to interactive effects that occur as consumers make sense of the environment holistically, rather than through piecemeal information processing (Baker et al. 2002; Bitner 1992).

Research on servicescapes in non-retail settings has received relatively limited attention from services scholars (Hightower, Brady, and Baker 2002). For example, in a particularly illuminating study, Berry and Bendapudi (2003) showed how "managing the evidence" with servicescape design and even simple tangible cues can influence patients' hospital experiences and the healing process itself. In the hospitality and tourism literature, Bonn, Joseph-Mathews, Dai, Hayes, and Cave (2007) noted that researchers have focused on the effects of environmental 
factors on destination image. However, recognizing both the potential of servicescape strategy and the nature of consumers' responses to the servicescape, a stream of interdisciplinary research has emerged that explores the role of physical environments in experience design (Haeckel, Carbone, and Berry 2003; Pullman and Gross 2004). Implicit to this work is the idea that consumers may seek certain consumption environments such as restaurants, hotels, themed retail stores, and leisure services not only for the obvious functional benefits (e.g., meals, lodging, goods), but for the experiential benefits - sensations, emotional arousal, knowledge, and memories (Pine and Gilmore 1999; Sherry et al., 2001; Wakefield and Blodgett 1994). The experience itself is the sought-after product (Otto \& Ritchie, 1996).

Kwortnik and Ross (2007) define an experiential product as "fusing tangible (sensory) and intangible (symbolic) attributes and co-produced by consumer and marketer to create an event that is pleasurable, meaningful, and memorable.” For experiential products, a welldesigned servicescape establishes the context in which the service is performed (Bitner 1992; Pullman and Gross 2004). Using a theater metaphor, Grove, Fisk, and Bitner (1992) suggest that the servicescape is like the setting for a play; service scenery and props set audience expectations and impressions, as well as facilitate performance of actors (service employees) on the service stage. Pine and Gilmore (1999) popularized this idea, arguing that services can be elevated to experiences by paying attention to themes, cues, and evoked sensations.

Although studies conducted in retail contexts are important for revealing the process of servicescape influence on consumers, the generalizability of this research to experiential-product contexts is uncertain for several reasons. First, retail encounters (e.g., banking, dry cleaning, grocery, and clothing) typically are shorter in duration than experiential-product encounters (e.g., fine dining, theme parks, spectator sports, and cruises). Extended service encounters increase opportunities for the customer to interact with and be influenced by the servicescape (Wakefield and Blodgett 1994; Wall and Berry 2007). Second, except for themed retail outlets (e.g., Niketown), retail contexts are less likely to be sought by consumers for the setting than are experiential products (Wall and Berry 2007). Third, the nature and salience of goals consumers bring to retail versus experiential settings differ (Wakefield and Blodgett 1994). For example, in retail settings, salient consumer goals are more likely to be functional and utilitarian (e.g., value convenience, and problem resolution), whereas in experiential contexts salient goals are more likely to be hedonic and symbolic (e.g., stimulation, challenge, and self-extension) (Kwortnik and Ross 2007). By extension, mediating factors expected to affect attitudinal and behavioral consumption outcomes will differ. Service quality and value perceptions play a main mediation role in retail contexts (Baker et al. 2002), whereas positive emotion is also a key mediator of the servicescape in experiential-product contexts (Hightower et al. 2002; Pullman and Gross 2004; Wakefield and Blodgett 1994). Finally, though servicescapes produce a "message-creating medium" for most services (Wall and Berry 2007), we propose that atmospheric clues will be more important in experiential-service contexts for consumer meaning making in terms of the brand, the experience, and associated social and self-identity (Aubert-Gamet and Cova 1999; Bonn et al. 2007; Levy 1999). In sum, servicescapes and the physical and social factors contained therein are critical to monitor and manage both in terms of the micro-level effects of servicescape elements and also for the holistic sense of context and meaning consumers derive from their interpretations of servicescape clues.

\section{Shipscapes}

The study conceptualizes a shipscape as a context-specific type of servicescape that includes both the man-made physical and social environment in which the cruise service is delivered (the ship), as well as the natural environment (the ocean) that provides a broader 
experiential context. Modern cruise ships simultaneously direct attention to and away from the sea. For example, new ships offer many outside cabins with private balconies, once a luxury available only to passengers who booked expensive suites. Balconied cabins enhance a unique aspect of cruising: the experience of being at sea. However, cruise ships also focus passengers' attention inward through the use of shipscape elements, such as million-dollar art collections that adorn public spaces and the grandiose-some would say, outrageous- - "entertainment architecture" designed to be utterly unlike most anything passengers might experience at home (Kwortnik 2006). RCI took this to a new level with the "Royal Promenade" shopping plazas aboard its new ships ("rather like a mall with a ship built around it"; Ward 2005, p. 128). Especially novel about this design is that many inside cabins on these ships overlook the promenade, whereas inside cabins on other cruise ships offer no view at all.

This focus on the cruise ship's internal shipscape is not new. Historians note that the ocean liners of the early $20^{\text {th }}$ century featured public spaces-lobbies, restaurants, libraries, ballrooms, smoking rooms, and even palm courts-modeled after the great hotels of Europe and the United States. Not only were these rooms designed to appeal to the sophisticated tastes of first-class travelers (spaces for third-class and steerage passengers were spartan, at best), but these early shipscapes directed passengers' attention inside the ship and diverted attention from the often surly seas of the North Atlantic (Miller 1985).

Cruise vacations are a prototypical experiential product; modern cruise ships are a combination floating resort hotel, sightseeing vessel, gourmet restaurant, food court, nightclub, shopping center, entertainment complex, and recreation facility. Cruises offer a range of services, from the utilitarian offerings of transportation, lodging, and meals, to the intangible symbolic, emotional, and hedonic benefits embedded in pampered personal service. Cruise programs feature all manner of participatory social and learning options, from parties for passengers with shared hobbies or interests, sporting contests, and games, to wine-tasting and art auctions, dance lessons, expert lectures, cooking and dessert-making demonstrations, computer classes, and more. Garin (2005, p. 198) opined that cruise ships "exist to produce nothing but the immediate experiences of pleasure and satisfaction.” Indeed, because transportation is no longer the primary function of passenger shipping, the very nature of the product has changed. Characterizing the cruise industry as illustrative of the process of "destination," Weaver (2005, p. 166) commented that "for many tourists, super-sized cruise ships have become the centerpiece of the cruise holiday. The ship has, in essence, become the trip."

During the heyday of passenger shipping before the jet airplane changed the way people traveled in the late 1950s, shipping companies battled for supremacy in terms of whose ship was the largest, fastest, or most opulent (Miller 1984). Years later, in the early 1970s, the upstart Carnival Cruise Lines made a bold differentiation move not by promoting the destinations the company sailed to, but instead by focusing attention on the ship as the destination and the fun that could be had on board, thus giving rise to the company's positioning as the "Fun Ships" (Dickinson and Vladimir 1997). Cruise lines try to differentiate from competitors through physical product innovation. However, some researchers suggest that this competition may produce the opposite effect - a dilution of the cruise experience and homogenization of the shipscape across brands (Kwortnik 2006; Ward 2005; Weaver 2005a). The trend toward bigger, themed spaces does beg the related questions: What is a cruise? And, how does the shipscape influence passengers' co-production of cruise meanings and experience? These questions anchor the empirical study described next. 


\section{METHOD}

\section{Data Collection}

In light of the discovery-oriented objective of this research, qualitative data and an interpretive analytic method are used to develop an understanding of the cruise experience in general and the role of the shipscape more specifically from the cruisers' perspective. To hear the voice of the cruiser and tap into their lived experience (Thompson, Locander, and Pollio 1989), data was collected from discussion boards on the Website, CruiseCritic.com, an online global community comprised of more than 219,000 members, 401,000 threads, and 6.8 million posts. Topics discussed on CruiseCritic run the gamut from reviews of cruise lines and ships, to tips for packing, dining, shore excursions, and more. Participants in the community are diverse, from first-time cruisers to veterans of dozens of sailings. They are identified by their screen name and sometimes an avatar, the date they joined the community, their location, and the number of posts to date (in our dataset, one participant was posting for the first time, whereas another had more than 10,000 posts). Some participants include information (e.g., age, marital status, occupation, and interests) in an accessible public profile. Many posters also like to list their past cruises, including cruise line, ship, and year; some even include a countdown ticker to their next cruise.

Data were collected unobtrusively; the analyses mine archived discussion boards without participating in the discussion. Given the volume of data on CruiseCritic, it was necessary to focus data collection on the topic of interest. However, we had no specific expectations about the role of shipscapes in the cruise experience. To help keep a priori assumptions in check, data was collected by an undergraduate research assistant unfamiliar with the servicescape literature, who was instructed to look for any general or specific discussion of the physical environment of a cruise. She did this by conducting an automated key word search of CruiseCritic discussion threads using words associated with servicescapes, such as décor, layout, atmosphere, facilities, lighting, smell, sound, etc. However, because cruisers were apt to use common language (e.g., "blaring music") and examples (e.g., "pillows and comforters-so soft!") instead of descriptive terms when referring to shipscape elements, she randomly scanned the discussion boards for such illustrations. Instances of context-specific shipscape elements, such as the motion of the ship and its effects were also collected. In this manner, the data collection process was both systematic (key word searches) and random (exploration for examples), as well as iterative and grounded in the cruiser's language and experience. The sum of this effort is a data set that captures 260 unique cruiser voices across 63 threads, producing 78 pages of data.

\section{Data Analysis}

Data were analyzed by applying the basic tenets of grounded theory (Strauss and Corbin 1998). We first identified cruiser references to the ship environment, some of which were merely observations (e.g., "Inside cabins tend to be dark.”). Such statements were usually accompanied by evaluations and impressions that provided an emic perspective (using terms meaningful to the cruiser) of the hedonic effects of the shipscape. When emic views were not present, the data were coded for meaning based on an etic analysis (researcher interpretations of meaning) within the context of the cruiser's full comment as well as the broader context of the discussion thread from which the comment was mined. Data elements were organized using Bitner's (1992) conceptual framework for assessing servicescape effects and Baker's (1986) ideas about social factors in the service environment. To develop a deeper understanding of shipscape meanings and influences, data elements that shared conceptual properties were explored for patterns and themes using constant comparative analysis (Strauss and Corbin 1998). 


\section{FINDINGS}

For many people, a leisure cruise can be other-worldly, even sacred experience (Belk, Wallendorf, and Sherry 1989)—especially for cruise fans like those travelers who populate online cruise communities. Cruisers often speak of a sense of awe upon seeing ships for the first time or upon exploring ships' interiors. Elements of the shipscape can enhance this sacred experience, as well as other goals that cruisers bring to their journey (e.g., romance or escape); yet, the shipscape can easily make the experience profane, such as when unpleasant noises, smells, or motion interfere with experiential goals. Moreover, because a cruise ship serves multiple purposes - home away from home, entertainment center, attraction, social gathering space, dining venue, etc. - cruisers pay attention to and derive personal meaning from shipscape clues in simple and surprising ways. We examine this cruiser interaction with the shipscape next, first by framing our findings in terms of cruisers' consumption goals and then by examining the different influences of the shipscape on cruisers' hedonic experience.

\section{Why People Cruise}

Research reveals an array of reasons why people choose to cruise, including: 1) A cruise takes you away from it all; 2) A cruise is a hassle-free vacation; 3) You're pampered; 4) You can do it all or nothing at all; 5) A cruise is a romantic experience; 6) A cruise is something new (Mancini 2004). In reference to reason \#1, Mancini (2004, p. 17) notes, "Smog, pollution, traffic, alarm clocks, beepers, ringing telephones, chattering fax machines-these are not what a cruise is all about. Cruises are instead about water, sea, sky, and landscape-the simple things that touch us so deeply." Cruisers found on CruiseCritic support these reasons for cruising and reveal other goals common to tourism experiences, such as discovery, escape, relaxation, choice, and “otherness" (Pearce and Lee 2005; Kwortnik and Ross 2007). For example, in a thread dedicated to $\mathrm{P} \& \mathrm{O}$ cruise line, Skyrules of Brisbane (1,029 posts) states, "I enjoy just being able to go away and relax - have the mundane stuff (cooking, cleaning, etc.) done for you, and being able to choose to do as little or as much as you like. Cruising has to be one of the most relaxing ways to holiday." Analyzing the cruise experience by keeping in mind experiential goals and expectations illuminates the influence of the shipscape.

\section{Ambient Conditions: Simple Cues and Significant Effects}

The effects of shipscape elements on the cruise experience vary greatly, from simple physiological responses to more complex symbolic meanings. The same shipscape stimulus (e.g., motion of the ship) might elicit a range of responses both within and across cruisers. Discussion of ambient conditions was infrequent when compared to topics that attract cruisers' attention (e.g., entertainment, food, service, destinations). However, when ambient conditions are salient, so are the (typically negative) effects. For example, HMK of New York (145 posts) was quite aware of cleanliness, describing the ship she sailed on as "beautiful!!! Very clean!!!” and her cabin as "Very clean, large!" However, she also stated: "I did notice a sewer smell coming from the toliet (sic) ..., by the next day the smell got worse. Spoke to our cabin steward about it, but nothing happened. By the following day....it was unbearable.” Similarly, a cruiser on a ship that had just reentered service after repair for a fuel-system problem felt that the ship was not ready, as it still smelled of fuel oil: "It was nauseating." Smoking aboard ship was a common lament of cruisers, with many saying that excessive smoking was enough to make them reconsider sailing with certain cruise lines. Commented caviargal of Florida (5,575 posts) [The ship was] overcrowded, smoky, and congested... The bars were so smoky, I could not stay for more than a few minutes.” Consistent with research in other service environments (e.g., Chebat and Michon 
2003; Mattila and Wirtz 2001), odors induce feelings of (dis)pleasure, arousal and consequent approach — or more typically in this data set-avoidance behavior.

Cruisers also complained about another kind of ambient pollution: noise, from the chattering of the ship's structure itself in rough seas to the noise of workers doing maintenance. More often the source of noise was other cruisers, a finding that underscores Baker's (1986) inclusion of social factors as aspects of the service environment that affect the customer experience. For example, Poppa_Daddyo (93 posts) stated that cabin noise was worse than he expected on his cruise. He advised other cruisers to bring earplugs, especially for staying in a cabin that adjoined another: "We had the worst neighbors - a 4mo baby who screamed nonstop for 90 minutes, followed by the next night of shouting, banging, slamming, etc until 2 am, when I finally called security. You can hear *everything*." Similarly, I\&MsMom (1,103 posts) noted, "It was very quiet ... with the exception of those getting up to watch the sunrise letting their doors close. What is barely noticeable during the day is deafening in absolute silence. A plea to you early risers ... please catch your door before it "slams" closed."

Noise of a different and surprising sort—music — also affected the experience of many cruisers and was a concern for cruise shoppers. For example, some cruisers worried about hearing too much country music on a ship that departed from the port of Galveston, TX, as they wanted to hear "island music" to set the vacation mood. Ambient music was a particular source of dismay among cruisers of Holland America Line, a company that typically attracts an older clientele. Kicking off the criticism was SLove (13 posts), who asked, "Why did HAL change? In ... areas where passengers roamed there was constant and loud music playing. Not the kind of music that we are used to on HA, but ... the rock and roll variety and loud at that. Just felt really out of place especially in Alaska." Happy cruzer (498 posts) chimed in, "Please tell me they did not pipe music in on the promenade deck. I love sitting there in my deck chair listening to the sea breeze and the ocean. I could deal with almost anything but that. Joining the unhappy chorus, uncialman (256 posts) argues:

The current choice of ambient music is not indicative of a premium, refined, culturally sophisticated product. This change in on board music creates a completely different atmosphere ... foreign to Holland America Line guests that were promised a "traditional cruise experience....” I was just talking to an older man next to me in the internet café. The gentleman stated "no matter where you go the music seems to follow you around...." I’m just a bit frustrated right now and apparently no one at HAL really cares.

These cruisers decry the intrusion of noise in the shipscape, the inability to escape it, and the effect this has as it impinges upon the tranquility of the experience and the "sounds of the sea." Moreoever, they link the ambient music to the meanings associated with the HAL brand, noting the dissonance between the loud, ever-present music and their impressions of HAL as a more sophisticated, traditional, “culturally refined” experience.

Cruisers were similarly sensitive to shipscape lighting, from the "wild and crazy” lighting in some atriums, to the "cool black light" outside a nightclub that would make white glow. While most comments about lighting were positive, talk about dining-room lighting took on a different shade. For example, Mrs. Bunder of Peabody, MA (35 posts), stated that a recent cruise did not have candlelit tables in the dining room, but instead only had overhead lighting. She opined, "To me, this took away from the whole dining room experience; our first ... cruise was ... about 4-5 years ago, and they had candlelight in their dining room. Can anyone comment on this?” CoconutFish of British Columbia (75 posts) agreed: 
We have always found the dining room to be lit up much too brightly, to the point that it is headache-inducing.... Especially on formal night? Bright is very casual; a bit of "mood lighting" on formal night would add to the ambiance of a "special" evening.

As with the responses to music, these and similar posts reveal physiological and psychological responses to cruise lighting, with bright lighting in dining rooms producing negative perceptions of the experience. In such a context, bright lighting is not a congruent cue in support of the servicescape (i.e., fine dining) customers expect (Babin, Hardest, and Suter 2003) and meanings such as romance, sophistication, and a "special” experience that they seek.

Another ambient condition that one would expect to be particularly salient for cruisers is ship motion and consequent physical discomfort. Seasickness is often a source of concern for first-time cruisers (Mancini 2004). Noted one new cruiser, Charlikin (36 posts), "I had trouble at first getting used to the fact that the ship *moved*, and watching the water rush by ... was, er, not too pleasant for me.” Veteran cruisers talk about ship motion with a mix of acceptance, fortitude, and, interestingly, pleasure ("the motion of the ocean rocks me to sleep"). They recount stories of rough voyages and trade tips for which therapies are effective at reducing discomfort or which cabin locations are less susceptible to motion. Smeyer418 of New York City (5,439 posts) quips: "All ships rock and roll.... Some people get seasick in absolutely calm waters. Some don't get sea sick at all, and for god sakes look at the horizon... if you watch the bow you will feel the motion much more.... excuse me I have to go throw up.” Some cruisers find a ship's motion to be an enjoyable, unique part of the experience. Charlikin (36 posts) describes the fun had with fellow cruisers as they tried to contend with the ship's motion when walking to/from their cabins:

We had to walk over a section that wasn't carpeted and that had raised pieces like speed bumps - we were hysterical navigating these as we couldn't walk a straight line anyway (much less speed through) due to the motion of the ship. We were laughing so hard one night that our neighbors refused to believe all we'd been drinking was club soda!!!

The issue of motion discomfort is unexamined in the atmospherics and servicescape literature, yet this ambient element of the shipscape has a large impact on the cruise experience and on cruisers' decisions about time of year to cruise, which cabins to book, and whether to cruise at all. In addition, for some cruisers, the "motion of the ocean" is a unique aspect of the experience that distinguishes cruising from other vacation alternatives (e.g., beach resorts) that offer similar amenities and benefits-but not the experience of being at sea.

As shown by data highlighted in this section, cruisers attend and respond to a variety of ambient stimuli present in the shipscape. Some ambient conditions such as music that are designed to enhance the pleasure of cruising may have the opposite effect when perceived as intrusions that detract from the expected experience and sought-after meanings; on the other hand, a potentially negative ambient condition such as the pitching and rolling of a ship at sea is experienced by some people as a pleasurable, unique, even desirable aspect of cruising. These findings extend the literature on atmospheric effects by revealing experiential and symbolic (i.e., meaning-making) consequences of consumers' interactions with the shipscape beyond the attitudinal and behavioral effects most often studied in atmospherics research.

\section{Shipscape Vacation Spaces: The Effects of Design, Layout, and Facilities}

In the past, cruise ship interiors, especially cabins, were functional but hardly luxurious (Miller 1985). This was particularly true of cruise ships that were converted ocean liners as 
opposed to purpose-built leisure cruise ships. By the late 1980s, ship design had evolved with the launch of the first “megaship” in 1987, RCI's Sovereign of the Seas, and Carnival Cruise Line's Fantasy in 1990, the first of eight sister ships that boasted flamboyant interiors, including themed public rooms, vivid colors, neon lighting, and reflecting surfaces (Cudahy 2001; Garin 2005). Thus began the "destintization" of cruise ships and an escalating competition among cruise lines for novelty. Judging by the comments of the CruiseCritic community, cruisers have benefited by this focus on design, layout, and facilities in the shipscape. However, not all cruisers are happy with the emerging trends in the industry.

Cruise ship cabins have traditionally been small, though new ships are often built with large suites or outside cabins featuring balconies, which increases the perception of space. The reaction of HMK of New York (145 posts) reflects this perception: "My first impression of our cabin was WOW!... I will only book a balcony cabin from now on. It is relaxing to sit on it, drink coffee, watch the sunrise....” The experiential benefits of balconies are echoed by other cruisers. Noted neverenufcruising of South Carolina (9,808 posts), who prefers an aft cabin, "We enjoy seeing where we've been, especially having a drink on the balcony as our own private sail away from each port." Cruznon (1,568 posts) concurs: "Aft cabins worth it? YES. The view is spectacular... the wake, the stars at night, the wide panorama!”

While cruise cabins can enhance the experience, displeasure with cabin conditions can detract from the comfort of one's vacation home at sea and impressions of a pampered vacation experience. Cruisers discussed lack of space, poor lighting, and tired furnishings. For instance, cavkc (384 posts), who stayed in a suite, described a beautiful foyer with mosaic tiles, a baby grand piano that was "quite fun," and a bedroom with a "very comfortable bed with the best cotton sheets I have ever experienced," but also furnishings "showing signs of wear," evidence of water damage on interior walls, and a "temperamental” Jacuzzi. Katiebeth (406 posts) echoed these concerns about the same cruise line: "I truthfully felt like we paid Ritz Carlton prices for Holiday Inn type accommodations.... After this summers (sic) experience ... we have been looking at other cruise lines.” In another discussion about a mass-market cruise line, cruisers commented on the cabin décor. Osiebosie of Thompson Station, TN (465 posts), stated, "I am a little tired of the orange color theme in the staterooms.” Added mabgab (257 posts), "Agree with room decor chage (sic) ... the white linnen (sic) with the orange is butt ugly." Finally, MonaCD of Prince Edward Island (37 posts) offered these observations to "tease" other discussion readers: Here's what is waiting for you when you get back from dinner...bed turned down, chocolate on the pillow, soft lights, a spectacular view at your bedside ... and an elephant [towel animal] in your bed. Sure a hot guy might have been better but what the heck, everything else is pretty darn spectacular.

These comments show that cruisers attend closely to cabin design as an element of their cruise experience. In fact, an emerging trend in the cruise industry is customers who personalize their cabins, such as by decorating hall-facing doors with streamers, special-occasion announcements, and pictures of relatives or hometowns. Such behavior is rare in service contexts examined in the literature and reflects both the uniqueness of the cruise vacation as extendedduration service for which the servicescape is more likely to play a role in the service experience (Wakefield and Blodgett 1994), and the symbolic significance of the shipscape as contributing to the cruiser's self-identity (Kwortnik and Ross 2007).

The importance of shipscape in influencing cruisers' experiences was not confined to the immediate surroundings of the cruise cabin. Cruisers were also affected by the layout and size of 
the ships. For example, several cruisers debated the benefits and drawbacks of the layout aboard one cruise line's ships. Jensenbeach (26 posts) kicked off the topic:

We did not like the layout of the [Z-ship] at all. We LOVED the crew and cannot say enough good things about the service.... The layout of the ship is strange ... many of the public rooms are hidden and tucked into obscure places. We are in the process of booking another cruise and are ambivalent about [this cruise line].

However, Bepsf of San Fransisco (4,758 posts) counters, stating: The smaller spaces ... are exactly why many of us prefer the line: we're simply not interested in the 'amenities' other lines provide such as massive indoor malls with bars and shops and hamburger joints endlessly lined up one after another, nor are we interested in Hyatt-Regency-style atriums with flaming-brass, light shows and glass elevators flying above our heads - that's the stuff many of us are trying to get away from... when we go on [this line's] cruises. I think many ... repeat passengers prefer the more intimate 'Country-House' atmosphere that [this line] provides.

This debate reveals the symbolic importance some cruisers attach to preferred cruise lines based on a characteristic of the product — ship layout—-that one would not expect to carry significant personal meaning.

The layout debate also highlights a tension occurring in many CruiseCritic discussions between advocates of larger vs. smaller ships, newer vs. older ships, and modern vs. traditional entertainment activities. Shipscape design, layout, and facilities are especially salient for cruisers and elicit the type of approach (attract, explore, stay) and avoid (repel, hide, leave) actions that Bitner (1992) outlines as behavioral responses to servicescapes. These aspects of the shipscape also interact with the people factor to create social effects on the cruiser experience (Wakefield and Blodgett 1994). For example, Jimsgirl of Charlotte, FL (683 posts), argues against the largership trend: "What is the use of having so many passengers trying to attend a function when there are not enough seats or breathing room? When it takes two hours to line up waiting to board or disembark? Tempers just get frayed.” However, other cruisers perceive the newest mega ships to be so spacious that they "never feel crowded." Analysis of the ship-size tension suggests a number of levels to the problem. At a more surface-level, cruisers express cognitive/behavioral concerns about crowding, lines, and waits on bigger ships with more people. At a deeper-level, cruisers express emotional/symbolic concerns about being part of a "herd" and feeling lost (literally and figuratively) amidst the mass of people-just another tourist in the crowd.

Most cruisers accept that larger ships are needed to keep pace with facilities innovationassuming that such amenities are desired. This issue led Patinthehat of Mississauga, ON (453 posts), to ask, "How far is too far? Do you want a cruise with the focus on great service and dining, or with the most stuff to do? What would be the item that will make you say: 'That is crossing the line?’” Ala-kat (492 posts) replied, "Bigger does not mean better. I prefer smaller on a cruise. Have no use for a rock climbing wall, skating rink, surfing, boxing, etc.... I have no problem entertaining myself.” Agreeing, Taters of Fairbanks, AK (1,059 posts), stated, "RCI went to (sic) far when they built ice rinks into their ships and shopping mall type promenades, facing inward instead of out to the ocean. We simply will not go on a ship that size or with those features." Continuing this theme, ladycaveat of Reston, VA (2,436 posts), notes, "I go on a cruise to enjoy the cruise, not all the new elaborate activities such as climbing walls, bowling alleys, or boxing rings. But then again, I don’t have kids....” 
Though these cruisers question the value of entertainment amenities, others relish the trend and provide new ideas: "ROLLER COASTERS!" "lazy river replaces jogging track," and "a playground with slides and swings for kids." Some cruisers suggested designs that connect the shipscape and seascape, such as an idea by AdGuyMike of Hollywood, FL (34 posts) to build ships with "deep V hulls [so that] the most sought after cabins will be the ones submerged well below the waterline. Imagine your room with a picture window view to the vast unexplored undersea world as you cruise the oceans.” Tatka of Franklin, MA (2,435 posts) agrees:

Honestly.. If I am at sea.. I want to know and see more about the sea. I can ice-skate or ride rollo-coasters (sic) on land... but I can't see underwater world there. 1) I really wish ships could have underwater observatories, maybe with scientists who could give a lecture. 2) Also I would really appriciate (sic) Omni Theater with movies about islands that we visited or will visit tomorrow. 3) Wouldn't it be cool if there was a restaurant with portholes (or even big windows) so we can see underwater?

As these ideas suggest, many cruisers view the design, layout, and facilities of the shipscape as integral not only to their pleasure derived from experience, but also a type of co-created reality where they make sense of what the experience is or should be.

\section{Social Effects of the Shipscape}

The influence of social factors in the servicescape on consumer experience has received relatively little research attention compared to studies of physical atmospheric effects (Baker et al. 2002). In a recent study of heritage/cultural tourism customers, Bonn et al. (2007) reported that social factors such as how courteous and knowledgeable service employees are had much less influence on visitors' attitudes, word-of-mouth, and intentions to return than did ambient and design elements. However, because of the extended service duration of most cruises and the bounded service environment, social factors are likely to play a more important role (Price, Arnould, and Tierney (1995). The data show that cruisers respond to varied social cues involving fellow passengers and ship crew-from the concerns about passenger crowds and noise reported previously to the surprises cabin attendants leave for guests during evening turn-down service.

Cruisers express strong feelings about the service staff with whom they have closely interacted, especially cabin attendants, waiters, and bartenders. On the CruiseCritic site, there are discussion threads dedicated to cruise staff, such as one entitled, "Let's Name Some of the Outstanding Crew on Your Ship.” This thread includes hundreds of posts offering thanks to cruise staff, stories of service encounters, and pictures of the featured staff taken by the cruisers. Cruisers speak of their favorite crew members in highly personal ways — using first names, detailing known biographical facts, describing them as "friends," and expressing strong feelings of affection, even love. For example, emd1 (531 posts) praised "SOUAD, our outstanding, beautiful, sophisticated blond waitress from Chile, who had the most beautiful tone and enunciation in her voice I have ever heard! I so looked forward to her every night.” Some cruisers even tell of exchanging email addresses with crew or of tearful goodbyes (most always with the passenger doing the crying) at the vacation's end.

A pervasive theme in these data is that favorite crew members create special experiences and cherished memories - and for this, they become more than just service providers, but true friends (Price and Arnould 1999). For example, jstewie23 of New Jersey (134 posts) describes several cruise staff who "helped make our honeymoon special," including "Delmark - best stateroom attendant! He made sure everything was just so, 2 times a day, every day. He also left the best towel animals (I looooove them) and always greeted us with a big smile every time he 
saw us in the hallway.” Favorite crew are described not only as being professional and efficient, but also fun, warm, genuine, kind, enthusiastic, welcoming, and possessing "amazing” skills, and the ability to remember names and special preferences. For instance, Tinalou of Melboune (81 posts) stated, "I loved how at home we felt and how the staff get to know you and make you feel like you have joined their big family.” Perhaps not surprisingly, when cruisers experienced poor service, the responsible crew members are described as unprofessional, impersonal, rude, and, in general, uncaring. Such good or bad personal service often has a strong influence on the cruiser's overall evaluation of the experience, with (dis)satisfaction expressed in stark, emotional terms, consistent with research on service quality (Parasuraman, Zeithaml, and Berry 1985). However, cruisers who are pleased with the social interaction with crew speak of an emotional attachment and desire for continued relationships that is rarely found in research conducted in the retailing context. We propose that such desire for cruiser-crew bonds is a function of the extended service encounter, opportunities for intimacy and self-disclosure, and bounded physical space found on cruise ships (Arnould and Price 1999).

Research in both retailing (e.g., Eroglu and Machleit 1990) and leisure (e.g., Wakefield and Blodgett 1994) contexts shows that consumers’ perceptions of crowding negatively influence consumption emotions, perceptions of the servicescape, and satisfaction with the experience. Because cruise ships are bounded spaces where consumers expect to relax in comfort, the negative effects of crowding are amplified. Cruisers' comment data reveals considerable displeasure with long lines and crowds-especially when such social factors were impossible to escape, such as during cruise embarkation and debarkation. For example, one passenger said that the worst aspect of his cruise was when the ship returned to the home port and crowds of people were called to exit at the same time ("a dreadful experience"). Cruisers also complained about crowded pools ("glorified bathtubs shared by 1000 other passengers over the course of the day") and pool decks with deck chairs "crammed together." On the other hand, some cruisers found it easy to adapt to these social factors. Mused stanimal of Texas (132 posts): "The more people who are waiting in line for the waterslide, rock climbing wall, bowling alley, etc., means that there are fewer people on my area of the deck where I am reading my book, or talking with my wife."

The social effects cruisers have on each other need not occur through direct interaction. For example, some cruisers interpret the mere presence of groups of other cruisers as affecting the shipscape, as when an "older crowd" creates "a more formal atmosphere," or when a large number of children or teens detract from the "adult ambiance" of a restaurant or lounge. Fellow passengers become part of the visual scene by blending into and shaping the physical dimension of the servicescape. This is particularly evident for cruisers in terms of wardrobe choices of other travelers (a topic of considerable debate), with cruise traditionalists ruing the casual garb-jeans, t-shirts, and baseball caps - that some travelers wear on the ship and even in the dining rooms. Such "underdressed" people are perceived to damage the more formal, elegant atmosphere that some cruisers believe makes the experience different from other types of vacations. However, other cruisers note that they choose certain cruise lines for the more casual experience and are ambivalent about how others choose to dress. Flyingpirate of beverly thrills (sic), CA (2,631 posts), explains that on his preferred cruise line, guests dress however they wish without any effect on her experience: “....certain of our fellow passengers share a desire for sartorial elegance and some look more at home at a NASCAR race or on the back forty." A common theme to this debate is the importance of "fit" - the fit between the wardrobe of other cruisers and the intended atmosphere of the cruise line, as well as between the cruise line and one's own self-identity. 


\section{The Symbolic Significance of the Shipscape}

As previous ideas about what shipscape elements should (not) or could (not) be suggest, cruisers are not only aware of how the shipscape influences their experience, but also of the symbols in the shipscape and how these define cruise brands-and themselves. Cruisers actively construct meanings using shipscape symbols_-and have their own ideas about how cruise lines might better use the shipscape to define what it means to cruise. The data suggest that this meaning making occurs on several levels, but most clearly at the brand level and at the broader cruise experience level.

For example, though non-Carnival cruisers often malign the Carnival Cruise Lines brand and its décor theme, Carnival's customers tend to enjoy the spectacle because the décor fits their experiential goals (fun and excitement) and their self-perceptions as high-energy vacationers. In contrast, cruise fans of Royal Caribbean prefer the less audacious décor of RCI's shipscapes. Comments Priusprof of Tampa, FL (160 posts):

Carnival doesn't have anything in the current fleet to compare to a Voyager Class Ship. It's like comparing the Holiday Inn to the Hyatt Regency.... The Royal Promenade with the shops and bars [is spectacular]. The 3 story dining room is eye popping. Different strokes for different folks though. If a longneck and dip is more your style ... stick with Carnival. If you are looking for a more sophisticated experience try RCCL.

In Priousprof's post, s/he derides the Carnival Cruise Lines experience, drawing symbolic comparisons to the mid-market Holiday Inn brand and a low-brow longneck beer and dip of chewing tobacco. In contrast, the shipscape of RCCL is symbolically equated to the higher-end Hyatt Regency hotel brand and a "more sophisticated” experience. Similarly, Croaziera (2 posts) highlights the active-adventure symbols of RCCL ships ("Promenade, Ice Skating Rink, h2o zone, rock climbing wall, flow rider") as evidence of quality and draws on meanings from another product category, cars, to symbolize quality differences between RCCL (“a Lexus”) and Carnival (“a Hyundai”).

Cruisers likewise use social cues in the shipscape as identity symbols. For example, Flyingpirate of beverly thrills (sic), CA (2,631 posts), is loyal to one mid-market cruise brand, though she claims she could "go with Regent or Crystal" [luxury brands], but "dropped out of the Junior League for a reason" and does not want to "travel with people like my parents.” In flyingpirate's choice of cruise line, she rejects the snooty image of higher-end brands and instead adopts the meanings of her preferred brand that offer "total freedom" to act and be whom she wants to be. She illustrates this brand-self congruity by stating proudly, "I went to a formal night in sequenced dress and slippers.” Echoing flyingpirate, utefan of South Jordan, UT (1760 posts), suggests that wardrobe - and by extension, cruise brand - choices are "partly a generational thing." She argues that dressing up when on a cruise vacation is fine, but "not my era, not my style...." She further suggests that more traditional and formal cruise experiences might "fit [someone else's] personality better," but for her, such cruise brands would "be a terrible fit."

These types of self-relevant meanings that cruisers derive from the shipscape are also evident in broader themes that relate how shipscape elements contribute to or detract from "the desired cruise experience.” Implicit in this theme is the notion that there is a something that is or is not THE cruise experience; however, this distinction is rarely clear and varies across cruisers. Whereas some cruisers enjoy the fun made possible by new onboard entertainment, others argue that "this is hardly a cruise anymore" and not what they seek in a cruise experience. Such criticism often takes the view that facilities, music, décor, and other factors that are readily available or omnipresent (e.g., blue jeans) “on land” contribute little to the cruise experience. For 
instance, MrPete of New York (6,104 posts) states, "Never had a need for the rock climbing wall (one right in the mall close to home)." GMoney (2,418 posts) claims that he is glad there are "no big water slides" on Royal Caribbean ships, as "there are plenty of places for people to have that kind of fun on land, and I think the slides can detract from ships aethestically (sic).” Lightsluvr of Oklahoma (904 posts) adds, "Slides look like a cheap municipal pool... pretty tacky." Commenting on the addition of outdoor movie screens on some ships, clgcrusier of Wisconsin (124 posts) notes:

My friends and I are going ..., and one of them is just thrilled about the big screen. I find this unnecessary, as I don't want to go on a cruise to watch movies-I feel it takes away from the experience!...I also don't go on a cruise to spend my time in an exercise room or a running track, or to climb a rock wall. . .I like to relax and watch the sea go by!

These comments reflect an idea that should be evident to customer-centric marketers: what cruisers want in the experience and the shipscape depends upon why they choose to cruise in the first place. The more difficult question is how to translate cruisers' stated (and unstated) needs into new ship designs without losing the essence of the experience of a vacation at sea. While we find evidence of cruiser pleasure in the entertainment architecture and facilities, analysis of the data across shipscape elements also reveals a tension between this brand of fun and cruiser notions of what the leisure cruise experience should be. The comments of lac of St. Albans, WV (6 posts), illustrate this tension:

I definitely vote no on water slides. Cruises are becoming more and more "adventure rides", which is fine for those who want that, but on a cruise I want cruise stuff....I also don't like the outside movie screens. If I want to watch TV I'll stay in my room.... On deck I want wind and water and pool sounds, and maybe a little pool music. I want to get away from the hectic lifestyle and noises of everyday life — not be inundated with media.

Lac's desire to "get away" mirrors what other cruisers describe as what they love about cruising. For Star-Man of Brisbane (107 Posts), the most enjoyable part of a cruise is "sitting at the outback bar ... late into the night ... with the sound of the sea being one of the only things that i could here (sic).” Finally, kezza of Kilsyth, Melbourne (153 posts) exclaimed:

I love the days at sea, laying back enjoying the rays, watching the beautiful blue waters, especially at the back of the ship with all the water churned up and frothy. I love the sunsets especially when you leave an island with the sun setting behind it. I love getting to the cruise terminal then that first step onto the ship. That's when I know my holiday’s begun!

\section{DISCUSSION}

The experiential environment of a cruise ship, the shipscape concept based on a conceptual parallel with Bitner's (1992) notion of the servicescape, is a complex physical and social context that must accomplish many things to produce a vacation experience at sea. Using qualitative data from an online cruise community, we explored the lived experience of cruisers to understanding how the shipscape influences their cruise experience and the meanings they construct about leisure cruising. We find that cruisers attend to myriad stimuli in the shipscapefrom the linens in their cabins to the wardrobe of their fellow cruisers. These stimuli produce an equally diverse set of physical reactions, thoughts, feelings, and behaviors. Figure 1 summarizes 
these effects in the organizing framework that extends Turley and Milliman's (2000) review of the influence of retail atmospherics.

Figure 1 about here.

Shipscapes possess atmospheric factors and induce consumer responses (the italicized items in the framework) that differ from retail servicescapes. This difference is because the leisure cruise and retail experiences are essentially different in four main ways: (1) Unlike the typical retail context, the cruise ship serves as a home away from home, which makes certain atmospheric factors particularly important to cruisers; (2) The cruise shipscape is a more salient and even sought-after part of the overall experience than the typical retail context; (3) Cruises are longer-duration service encounters than typical retail encounters, which enables ongoing social interaction and the development of perceived friendships between cruisers and crew members; (4) Compared to the retail context, the goals consumers bring to the cruise context are more likely to be hedonic, experiential, and symbolic than functional (i.e., problem-solving). The following discussion elaborates on the implications of these differences based on the findings and themes that emerged from the online cruiser data.

Cruise ships, in particular the newer vessels, are built for pleasure vacations — for dining, touring, gaming, socializing, and playing (Cudahy 2001; Yarnal 2004). Although cruise industry critics contend that cruise marketing creates vague expectations and that the experience does not connect with the customer emotionally (Klein 2002), we report data that challenge this. Cruisers expect a fun, relaxing, pampered, get-away experience, and their self-reports of excitement and aspects of cruising that they "love" indicates that cruises deliver on the sensational, emotional, experiential promise. Yet, aspects of shipscape can easily and dramatically interfere with experiential goals. Ambient pollution in the form of noise, music, odors, smoking, and ship motion, can negatively affect cruisers physically and psychologically. The broader theme represented by ambient effluence is that intrusion of the profane in the shipscape breaks the spell of the magical, even sacred cruise experience (Belk et al. 1989). Clearly, cruise ship designers, as well as the service team tasked with enacting the cruise performance must carefully attend to seemingly minor ambient irritants given the potentially serious negative effects on the physiological, emotional, and behavioral responses of cruise passengers.

Analysis of cruiser discussions about ship layout and facilities revealed a related theme: cruisers desire escape from the mundane elements present in their daily lives, yet the trend of larger ships (and consequent crowding and queues) and proliferation of amusement-park-like entertainment amenities and shopping malls that are also found "on land" hampers experiential escape and instead yields avoidance behavior (e.g., I will not sail on a huge ship with those features.). This response to the space/function of the shipscape supports criticism that modern ships designed for the mass-market tourist create "captive consumers" and "McDonalidized spaces (Weaver 2005a; 2005b). However, we also find that many cruisers are drawn to the entertainment architecture, are enchanted by it, and crave more of it (Weaver 2005b) - though some cruisers would prefer that future facilities focus less on amusement concepts and more on the shipscape-seascape connection. These tensions between larger vs. smaller ships and modern vs. traditional entertainment facilities can be expected to challenge cruise ship designers who strive to appeal to the broadest cruiser market and increasingly diverse preferences.

Interaction between and amongst cruisers and crew has a strong influence on cruisers' emotional and behavioral responses, but also on experiential and symbolic outcomes. Certain characteristics (e.g., age, actions, and appearance) of fellow cruisers affect perceptions of the shipscape ambiance. Cruisers react negatively to other travelers who disrupt desired experiential 
meanings (e.g., escape and sophistication) with smoking, noise, crowding, and overly casual dress. Similarly, crew members who are uncaring and unwelcoming make profane the expected extraordinary service experience. On the other hand, crew members who use their hospitality skills to help cruisers co-produce special cruise moments-and even who develop perceived friendships with cruisers-facilitate experiential and symbolic outcomes that are unexplored in the retail-servicescape literature.

Ultimately, these shipscape themes and tensions interact with cruiser needs and imbue symbolic aspects of the cruise experience-the meanings cruisers ascribe to and take away from their cruise vacation. In this respect, a cruise is more than just a hedonic activity, but is also a form of self-relevant meaning-making. However, when these meanings derived in part from the shipscape conflict with experiential goals and self-perceptions (e.g., deserved pampering, sophistication, and individualism), the results are discordant impressions and dissatisfaction. For example, we find that many cruisers seek some form of "real" cruise experience, much in the same way that land tourists pursue sacred places and "authentic" experiences through vacation pilgrimages (Belk et al 1989; MacCannell 1999). These authenticity-seeking cruisers rue the inauthentic - the shopping malls, boxing rings, arcades, and other diversions - that direct attention away from the seascape and instead inward toward the revenue-generating shipscape. They echo Ward's (2005, p. 103) comments, who argues that a cruise is not the experience offered by "the large resort ships [that] ... cram lots of people into small cabins and provide nonstop activities that insult the intelligence and assault the wallet." However, the popularity of cruises on ever bigger and busier ships suggests not only that many cruisers find pleasure in these experiences, but also that a new definition of what a cruise really is may be emerging.

\section{Limitations and Directions for Future Research}

Given the paucity of research on atmospheric effects in leisure and tourism settings, this study applies a discovery-oriented research objective, qualitative data, and an interpretive analytic method to strive for a richer understanding of servicescape effects in a novel context: leisure cruising. The findings and themes derived from the comments of 260 cruisers participating in an online cruise forum reveal a variety of atmospheric stimuli and consumer responses that are unique to the cruise context and extend our understanding of servicescape effects beyond the retail context. The textual data does not, however, permit inferences about causal relationships between atmospheric stimuli and consumer responses. Future research that uses experimental designs to test for causal effects between, for example, types of entertainment architecture or the strength of perceived friendships with crew and experiential outcomes would shed additional light on the influence of these factors in leisure contexts.

In addition, the nature of the naturally occurring data and the unobtrusive data collection method used in this study preclude the ability to drill down to deeper levels of meaning about the self-relevant outcomes of the cruise experience. Depth interviews or ethnographic approaches would permit more direct investigation of the symbolic responses (e.g., brand-self congruity and self-identity construction) to shipscapes. Indeed, this is a potentially fascinating area of future research—and one of significant practical importance for cruise marketers. For many cruisers, the increasing complexity of the shipscape has created convoluted experiential meanings. As suggested by the cruiser comment that led this paper, the feeling one gets aboard some ships is conflated, leaving cruisers unsure whether they actually experience a "cruise" or something different - a floating theme park for grownups. The findings presented in this paper suggest that research is needed from tourism scholars (and cruise executives) that listens to the voice of the cruiser to better understand shifting meanings - and the influence of the shipscape on the experiential and symbolic dimensions of the leisure cruise experience. 


\section{REFERENCES}

Aubert-Gamet, Veronique and Bernard Cova (1999), "Servicescapes: From Modern Non-Places to Postmodern Common Places," Journal of Business Research, 44, 37-45.

Babin, Barry J., David M. Hardesty, and Tracy A. Suter (2003), "Color and Shopping Intentions: The Intervening Effect of Price Fairness and Perceived Affect," Journal of Business Research, 56, 541-551.

Baker, Julie A. (1986), "The Role of Environment in Marketing Services: The Consumer Perspective," In The Services Marketing Challenge: Integrated for Competitive Advantage, eds. J. A. Czpeil, C. Congam, and J. Shanaham. Chicago: American Marketing Association, 79-84.

Baker, Julie A., Dhruv Grewal, and Glenn B. Voss (2002), "The Influence of Multiple Store Environment Cues on Perceived Merchandise Value and Patronage Intentions,” Journal of Marketing, 66 (April), 120-141.

Belk, Russel W., Melanie Wallendorf, and John F. Sherry, Jr. (1989), "The Sacred and the Profane in Consumer Behavior: Theodicy on the Odyssey, Journal of Consumer Research, 16 (1), 1-38.

Berry, Leonard L. and Neeli Bendapudi (2003), “Clueing In Customers,” Harvard Business Review, (February), 100-106

Bitner, Mary Jo (1990), "Evaluating Service Encounters: The Effects of Physical Surroundings and Employee Responses," Journal of Marketing, 54 (April), 69-82.

Bitner, Mary Jo (1992), "Servicescapes: The Impact of Physical Surroundings on Customers and Employees,” Journal of Marketing, 56 (April), 57-71.

Bonn, Mark A., Sacha M. Joseph-Mathews, Mo Dai, Steve Hayes, and Jenny Cave (2007), "Heritage/Cultural Attraction Atmospherics: Creating the Right Environment for the Heritage/Cultural Visitor," Journal of Travel Research, 45 (February), 345-354.

Brady, Michael K. and J. Joseph Cronin, Jr. (2001), "Some New Thoughts on Conceptualizing Perceived Service Quality,” Journal of Marketing, 65 (July), 34-49.

Chebat, Jean-Charles and Richard Michon (2003), "Impact of Ambient Odors on Mall Shopper's Emotions, Cognition, and Spending: A Test of Competitive Causal Theories," Journal of Business Research, 56, 529-539.

CLIA (2006a), "Profile of the U.S. Cruise Industry,” accessed October 2, 2006: http://www.cruising.org/press/sourcebook2006-midyear/profile_cruise_industry.cfm, New York: Cruise Lines International Association.

CLIA (2006b), “CLIA 2006 Cruise Market Profile Report of Findings,” accessed October 3, 2006: http://www.cruising.org/press/research/2006\%20Market\%20Profile\%20Study.pdf, New York: Cruise Lines International Association.

Conlon, Donald E., Linn Van Dyne, Morgan Milner, and Kok Yee Ng (2004), “The Effects of Physical and Social Context on Evaluations of Captive, Intensive Service Relationships," Academy of Management Journal, 47 (3), 433-445.

Cudahy, Brian J. (2001), The Cruise Ship Phenomenon in North America. Centreville, Md: Cornell Maritime Press.

Dickinson, Bob and Andy Vladimir (1997), Selling the Sea: An Inside Look at the Cruise Industry, New York: John Wiley \& Sons, Inc.

Eroglu, Sevgin and Karen A. Machleit (1990), "An Empirical Study of Retail Crowding: Antecedents and Consequences," Journal of Retailing, 66 (Summer), 201-221.

Ezeh, Chris and Lloyd C. Harris (2007), "Servicescape Research: A Review and a Research Agenda,” Marketing Review, 7 (Spring), 59-78. 
Garin, Kristoffer A. (2005), Devils on the Deep Blue Sea. New York: Viking.

Grove, Steven J., Raymond P. Fisk, and Mary Jo Bitner (1992), "Dramatizing the Services Experience: A Managerial Approach,” in Advances in Services Marketing and Management, Vol. 1, Greenwich, CT: JAI Press, 91-121.

Haeckel, Stephan H., Lewis P. Carbone, and Leonard L. Berry (2003), "How to Lead the Customer Experience,” Marketing Management, (January/February), 18-23.

Hightower, Roscoe, Michael K. Brady, and Thomas L. Baker (2002), “Investigating the Role of the Physical Environment in Hedonic Service Consumption: An Exploratory Study of Sporting Events,” Journal of Business Research, 55, 697-707.

Klein, Ross (2002), Cruise Ship Blues: The Underside of the Cruise Industry, Gabriola Island, BC, Canada: New Society Publishers.

Kwortnik, Robert J., Jr. (2006), “Carnival Cruise Lines: Burnishing the Brand,” Cornell Hotel and Restaurant Administration Quarterly, 47 (August), 286-300.

Kwortnik, Robert J., Jr. and William T. Ross (2007), “The Role of Positive Emotions in Experiential Decisions.” International Journal of Research in Marketing 24 (December).

Levy, Sidney J. (1999), Brands, Consumers, Symbols, \& Research, Thousand Oaks, CA: Sage Publications.

MacCannell, Dean (1999), The Tourist: A New Theory of the Leisure Class. Berkeley, CA: University of California Press.

Mancini, Marc (2004), Cruising: A Guide to the Cruise Line Industry, $2^{\text {nd }}$ Ed. Clifton Park, NY: Thomson Delmar Learning.

Masek, Theresa Norton (2005), “CLIA: A Retrospective,” in Cruise Thirty. New York: Cruise Lines International Association.

Mattila, Anna S. and Jochen Wirtz (2001), "Congruency of Scent and Music as a Driver of InStore Evaluations and Behavior,” Journal of Retailing, 77 (Summer), 273-289.

Mehrabian, Albert and James A. Russell (1974), An Approach to Environmental Psychology. Cambridge, MA: Massachusetts Institute of Technology.

Miller, William H. (1984), The First Great Ocean Liners in Photographs. New York: Dover Publications.

Miller, William H. (1985), The Fabulous Interiors of the Great Ocean Liners in Historic Photographs. New York: Dover Publications, Inc.

Otto, Julie E. and J. R. Brent Ritchie (1996), “The Service Experience in Tourism,” Tourism Management, 17 (3), 165-174.

Parasuraman, A., Valarie Zeithaml, and Leonard L. Berry (1985), A Conceptual Model of Service Quality and Its Implications for Future Research, “Journal of Marketing (Fall), 41-50.

Pearce, Philip L. and Uk-Il Lee (2005), “Developing the Travel Career Approach to Tourist Motivation,” Journal of Travel Research, 43 (February), 226-237.

Pine, B. Joseph, and James H. Gilmore (1999), The Experience Economy. Boston: Harvard Business School Press.

Price, Linda L., and Eric J. Arnould (1999), “Commercial Friendships: Service Provider-Client Relationships in Context,” Journal of Marketing, 63 (4), 38-56.

Price, Linda L., Eric J. Arnould, and Patrick Tierney (1995), “Going to Extremes: Managing Service Encounters and Assessing Provider Performance,” Journal of Marketing, 59 (April), 83-97.

Pullman, Madeline E. and Michael J. Gross (2004), “Ability of Experience Design Elements to Elicit Emotions and Loyalty Behaviors,” Decision Sciences, 35 (Summer), 551-578. 
Sloan, Gene (2006), “Freedom, a Ship of Firsts,” USAToday.com, posted May 11, 2006, http://www.usatoday.com/travel/news/2006-05-11-freedom-of-the-seas_x.htm, accessed September 20, 2006.

Sherry, John F. (1998), Servicescapes: The Concept of Place in Contemporary Markets, Chicago: NTC/Contemporary Publishing Company.

Sherry, John F., Robert V. Kozinets, Diana Storm, Adam Duhachek, Krittinee Nuttavuthisit, and Benet DeBerrey-Spence (2001), "Being in the Zone: Staging Retail Theater at ESPN Zone Chicago,” Journal of Contemporary Ethnography, 30 (4), 465-510.

Spangenberg, Eric R., Ann E. Crowley, and Pamela W. Henderson (1996), “Improving the Store Environment: Do Olfactory Cues Affect Evaluations and Behaviors? Journal of Marketing, 60 (April), 67-80.

Strauss, Anselm and Juliet Corbin. 1998. Basics of Qualitative Research: Techniques and Procedures for Developing Grounded Theory, $2^{\text {nd }}$ Edition. Thousand Oaks, CA: Sage.

Thomke, Stefan (2003), “R\&D Comes to Services: Bank of America’s Pathbreaking Experiments” Harvard Business Review, (April), 71-79.

Thompson, Craig J., William B. Locander, and Howard R. Pollio (1989), "Putting Consumer Experience Back into Consumer Research: The Philosophy and Method of Existential Phenomenology,” Journal of Consumer Research, 16 (2), 133-146.

Underhill, Paco (1999), Why We Buy: The Science of Shopping. New York: Simon and Schuster.

Wakefield, Kirk L. and Jeffrey G. Blodgett (1994), “The Importance of Servicescapes in Leisure Service Settings, Journal of Services Marketing, 8 (3), 66-76.

Wall, Eileen A. and Leonard L. Berry (2007), “The Combined Effects of the Physical Environment and Employee Behavior on Customer Perception of Restaurant Service Quality,” Cornell Hotel and Restaurant Administration Quarterly, 48 (February), 59-69.

Ward, Douglas (2005), Berlitz Ocean Cruising and Cruise Ships 2005. London: Berlitz.

Weaver, Adam (2005a), “The McDonaldization Thesis and Cruise Tourism,” Annals of Tourism Research, 32 (2), 346-366.

Weaver, Adam (2005b), “Spaces of Containment and Revenue Capture: 'Super-Sized' Cruise Ships as Mobile Tourism Enclaves,” Tourism Geographies, 7 (May), 165-184.

Yarnal, Careen Mackay (2004), "Missing the Boat? A Playfully Serious Look at a Group Cruise Tour Experience,” Leisure Sciences, 26, 349-372.

Yarnal, Careen Mackay (2005), “Casting Off: An Exploration of Cruise Ship Space, Group Tour Behavior, and Social Interaction,” Journal of Travel Research, 43 (May), 368-379.

Zeithaml, Valarie A., Mary Jo Bitner, and Dwayne D. Gremler (2006), Services Marketing: Integrating Customer Focus Across the Firm. New York: McGraw-Hill Irwin. 


\section{Figure 1 Shipscape Effects on the Cruise Experience}

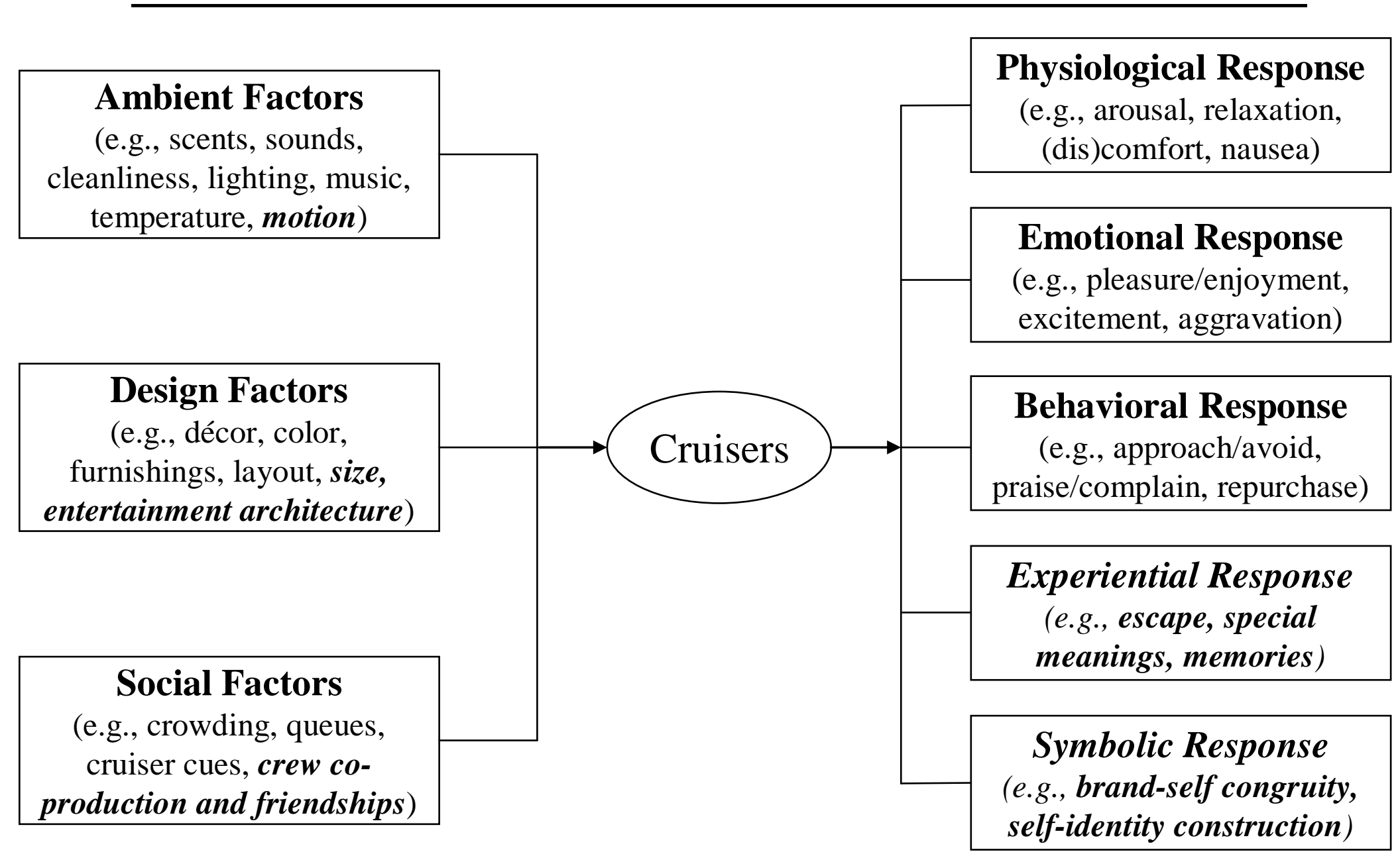

